\title{
FIRST RECORD OF OPILIO KAKUNINI SNEGOVAYA, COKENDOLPHER \& MOZAFFARIAN, 2018 (ARACHNIDA, OPILIONES, PHALANGIIDAE) FROM IRAQ
}

\author{
Shurooq Abdullah Najim* and Mustafa Jawad Al-Fayyadh** \\ *Natural History Museum, Basrah University, Basrah, Iraq. \\ **Agriculture College, Sumer University, Dhi- Qar, Iraq. \\ •Corresponding author: shurooq.najim@uobasrah.edu.iq
}

Received Date: 06 January 2021, Accepted Date: 20 March 2021, Published Date: 20 Jun 2021

\section{ABSTRACT}

The species of Opilio kakunini Snegovaya, Cokendolpher \& Mozaffarian, 2018 was recorded for the first time in Iraq; as well as to four species belonging to this order which were recorded previously. In this paper, we added a new species to the checklist of Iraqi opilionid fauna with a description of the most important characteristics, along with genitalia, for both males and females are presented with digital photographs. Specimens of males and females were collected from Al- Rifai district northern of Dhi-Qar Province, southern of Iraq.

Keywords: Dhi-Qar, First record, Iraq, Opiliones, Opilio kakunini, Phalangiidae.

\section{INTRODUCTION}

The order Opiliones or harvestmen is a major group of arachnids and contains 6,600 described species in 50 families worldwide (Kury, 2013).The order is divided into four suborders: Cyphophthalmi, Eupnoi, Dyspnoi and Laniatores. The suborder Eupnoi is divided into two superfamilies, the Phalangioidea which includes the long-legged forms, and Caddoidea a small group easily recognized by their huge eyes and spiny pedipalps (Cokendolpher et al., 2007).

The members of family Phalangiidae Latreille, 1802 are characterized by a soft body and relatively long legs, the tarsus of pedipalp is longer than the tibia, the claw is smooth, not toothed, palps and chelicerae clearly visible from above, the ovipositor is long and multisegmented, operculum flexible, the penis is shaft-like with a distinct glans held at an angle with the corpus, second leg usually longest, leg coxae without denticles (Cokendolpher and Holmberg, 2018).

The genus of Opilio Herbst, 1798 which belongs to subfamily Opilioninae, is diagnosed by the dorsum providing with small sharp denticles, mandibles short, coxae with brown spots 
ventrally, operculum genitalia with enlarged rounded top (Walker,1928). The opilionid fauna is poorly known in Iraq; according to Staręga $(1970,1973)$, there were four species only have been recorded: Rilaena gruberi Staręga, 1973; Rilaena hyrcana (Thorell, 1876); Opilio coxipunctus (Sørenson, 1912) and Dicranolasma kurdistanum Staręga, 1970.

The present study provides new data on the opilionid fauna of this region. Opilio kakunini, reported for the first time in Iraq. Digital images of both male and female habitus, genitalia and brief comments are provided regarding the identification of Opilio species in Iraq.

\section{MATERIALS AND METHODS}

The study was conducted at Al-Refai District, Dhi-Qar Province, Southern Iraq (Map 1), coordinates $46^{\circ} 10^{\prime} 03.383^{\prime \prime} \mathrm{E} ; 31^{\circ} 38^{\prime} 12.334^{\prime \prime N}$, during the period from 30 January to 30 July 2020.

The individuals were collected by hand during the night time. All the specimens were found on tree trunks, among the grasses or under the debris. Then, they preserved in $80 \%$ ethanol and deposited in Natural History Museum, Basrah University under the museum number (4 a, b).The specimens were studied and photographed using an AmScope MD200 camera installed on AmScope binocular dissecting microscope. The identification was done according to Hillyard and Sankey (1990) for identifying the genus, whereas the species was identified according to Snegovaya et al. (2018).

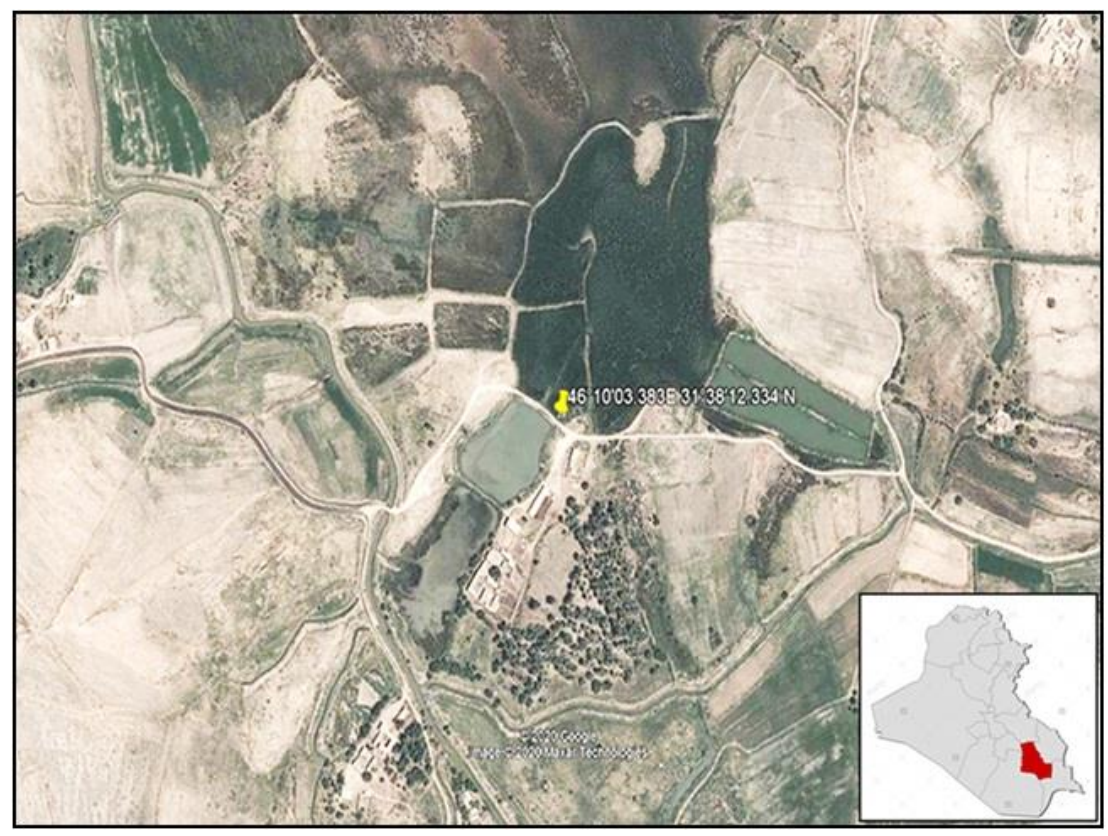

Map (1): Site of collection region. 


\section{RESULTS AND DISCUSSION}

\section{Morphological description}

Male (Pl. 1 A-I)

Coloration: yellowish brown, dorsum furnished with transverse rows of denticles, body oval shaped 4.6mm length and $2.7 \mathrm{~mm}$ width (Pl.1A). Ocularium: low with two rows of 5-6 black black-tipped denticles (Pl.1E).Chelicerae: basal segment1.4mm length with black- tipped denticles and setae dorsally, distal segment $1.8 \mathrm{~mm}$ length with small denticles and setae dorsally and few small spines laterally (P1.1C, D).Pedipalp:4.8 mm length, coxa of pedipalp with few setae and one black- tipped tubercle ventrally (P1.2A). Femur with setae and blacktipped denticles dorsally (Pl. 2B). Patella with denticles and setae dorsally (Pl. 2C). Tibia with small denticles ventrally (Pl.2D); tarsus with a rows of setae dorsally and microdenticles ventrally (Pl. 2E); claw smooth without pectination. Pedipalp measurements: Coxa $0.6 \mathrm{~mm}$, femur $1.2 \mathrm{~mm}$, patella $0.4 \mathrm{~mm}$, tibia $0.8 \mathrm{~mm}$, tarsus $1.6 \mathrm{~mm}$, claw $0.2 \mathrm{~mm}$. Legs: long, yellowishbrown, ventral side of coxae with a dark spot. Femur I cylindrical furnished with large blacktipped denticles (Pl.1B).

Legs length measurements: First leg $18.5 \mathrm{~mm}$ length, second leg $38.0 \mathrm{~mm}$ length, third leg $23.0 \mathrm{~mm}$ length, fourth leg $30.0 \mathrm{~mm}$ lengths.

Penis:(Pl.1F-I) Medium-size, length $(2.7 \mathrm{~mm})$; glans long, pear-shaped, $0.4 \mathrm{~mm}$ length $(\mathrm{Pl} .1 \mathrm{H}-$ I), wings oval shape, corpus widened in the basal third then tapers to the glans, stylus $0.2 \mathrm{~mm}$ length.

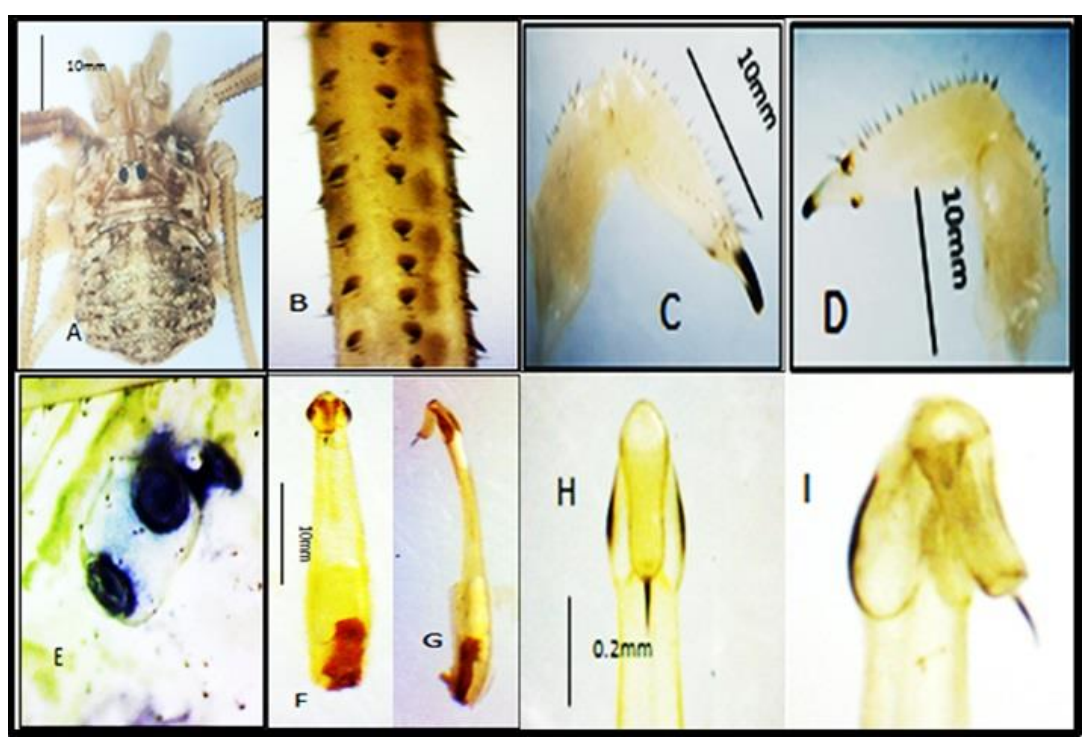

Plate (1): Male of Opilio kakunini; (A)Male body, dorsal view,(B) First femur, (C) Left chelicera, prolateral view, (D) Left chelicera, retrolateral view, (E) Ocularium, dorsal, (F) Penis, dorsal view, (G) penis, lateral view,(H) Glans, dorsal view, (I) Glans, lateral view from right. 
First record of Opilio kakunini

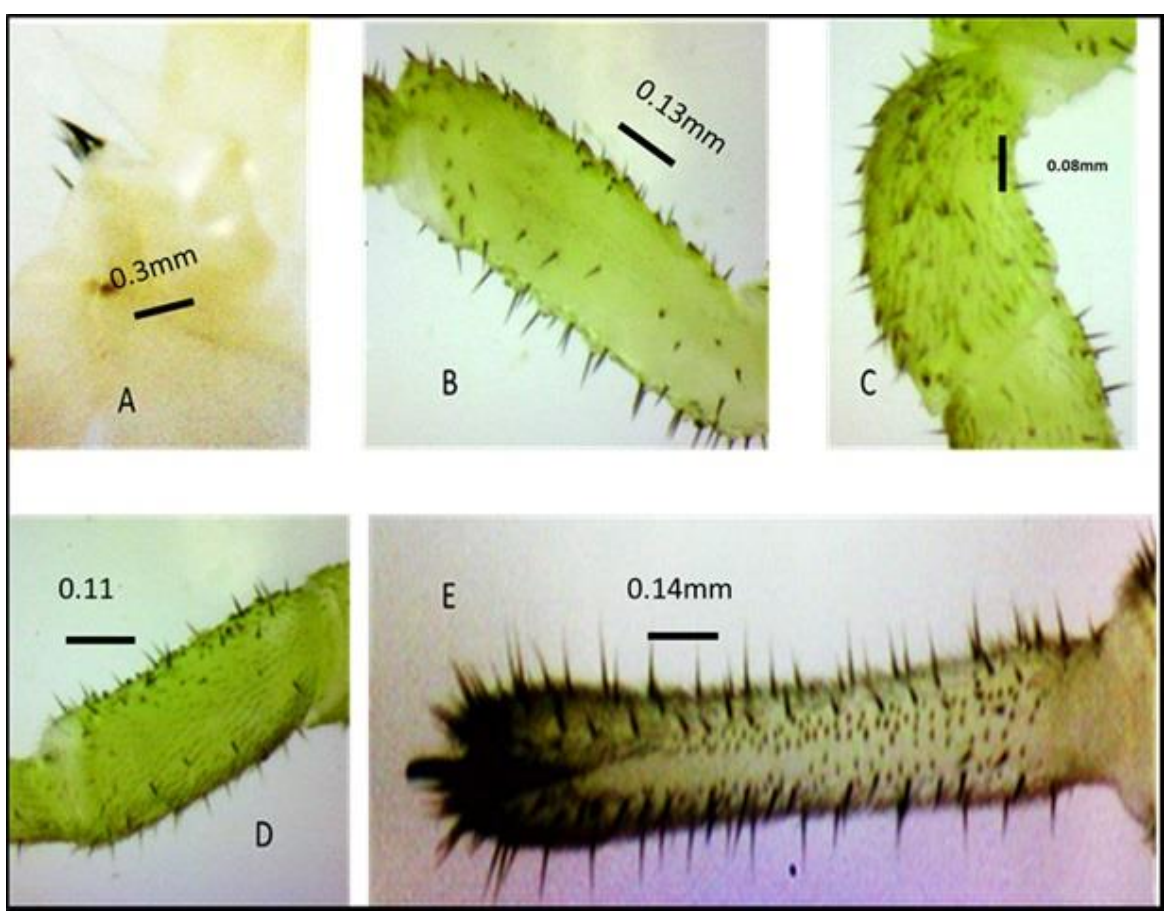

Plate (2): Male pedipalp of Opilio kakunini; (A) Coxa, (B) Femur, (C) Patella, (D) Tibia, (E) Tarsus with claw.

Female (Pl.3 A-I):

Body oval shaped; length $(6.2 \mathrm{~mm})$, width $(3.8 \mathrm{~mm})$, with transverse rows of small denticles on abdomen dorsally (Pl.3A-B). Chelicerae: yellow with setae dorsally, basal segment $1.2 \mathrm{~mm}$ length, distal segment 1.6mm length (Pl.3E-F). Genital operculum as in Plate (3G).Ovipositor long and segmented (Pl.3C-D), seminal receptacle with $1.6 \mathrm{~mm}$ in length.

Female resembles the male except differences in size and coloration. Female is larger than male, coloration is darker, armature of pedipalp much reduced, tarsus ventrally without microdenticles, and chelicerae without denticles.

Materials examined: $13 \hat{\partial}, 21 \rho q$, the date of specimens collection and data of environmental conditions were described in Table (1). 
Najim and Al-Fayyadh

Table (1): Number of individuals, specimens' collection date and environmental conditions.

\begin{tabular}{|c|c|c|c|c|}
\hline $\begin{array}{c}\text { No. of } \\
\text { individuals }\end{array}$ & $\begin{array}{l}\text { Date of } \\
\text { collection }\end{array}$ & $\begin{array}{c}\text { Maximum } \\
\text { temperature }\left({ }^{\circ} \mathrm{C}\right)\end{array}$ & $\begin{array}{c}\text { Minimum } \\
\text { temperature }\left({ }^{\circ} \mathrm{C}\right)\end{array}$ & $\begin{array}{c}\text { Relative } \\
\text { humidity \% }\end{array}$ \\
\hline $1 \hat{0}, 1$ 오 & 30.i.2020 & 20.5 & 8.0 & 65 \\
\hline 10,1 우 & 31.i.2020 & 22.1 & 7.0 & 54 \\
\hline $10 \hat{0}, 20$ & 08.ii.2020 & 20.0 & 9.0 & 40 \\
\hline 29 & 16.ii.2020 & 22.5 & 10.0 & 43 \\
\hline $2 \hat{\sigma}, 3$ 우 & 25.ii.2020 & 25.8 & 16.0 & 82 \\
\hline $1 \hat{0}, 2$ 오 & 29.ii.2020 & 25.0 & 12.0 & 52 \\
\hline 1 오 & 04.iii.2020 & 24.0 & 11.5 & 42 \\
\hline $10^{\hat{\alpha}}, 1$ 웅 & 05.iii.2020 & 25.0 & 11.0 & 43 \\
\hline 19 & 13-iii.2020 & 29.0 & 19.0 & 35 \\
\hline 10,29 & 15.iii.2020 & 26.0 & 17.0 & 45 \\
\hline $2 \hat{0}, 19$ & 01.iv.2020 & 31.0 & 18.0 & 29 \\
\hline 19 & 08.iv.2020 & 34.0 & 19.0 & 41 \\
\hline 10 & 29.iv.2020 & 30.0 & 23.0 & 31 \\
\hline $10^{\lambda}$ & 02.v.2020 & 38.0 & 20.0 & 17 \\
\hline $1 \delta^{\pi}$ & 18.v.2020 & 35.0 & 21.0 & 27 \\
\hline 1 오 & 30.v.2020 & 37.0 & 23.0 & 29 \\
\hline 19 & 03.vi.2020 & 42.0 & 26.0 & 15 \\
\hline 19 & 28.vii.2020 & 44.0 & 27.0 & 10 \\
\hline
\end{tabular}
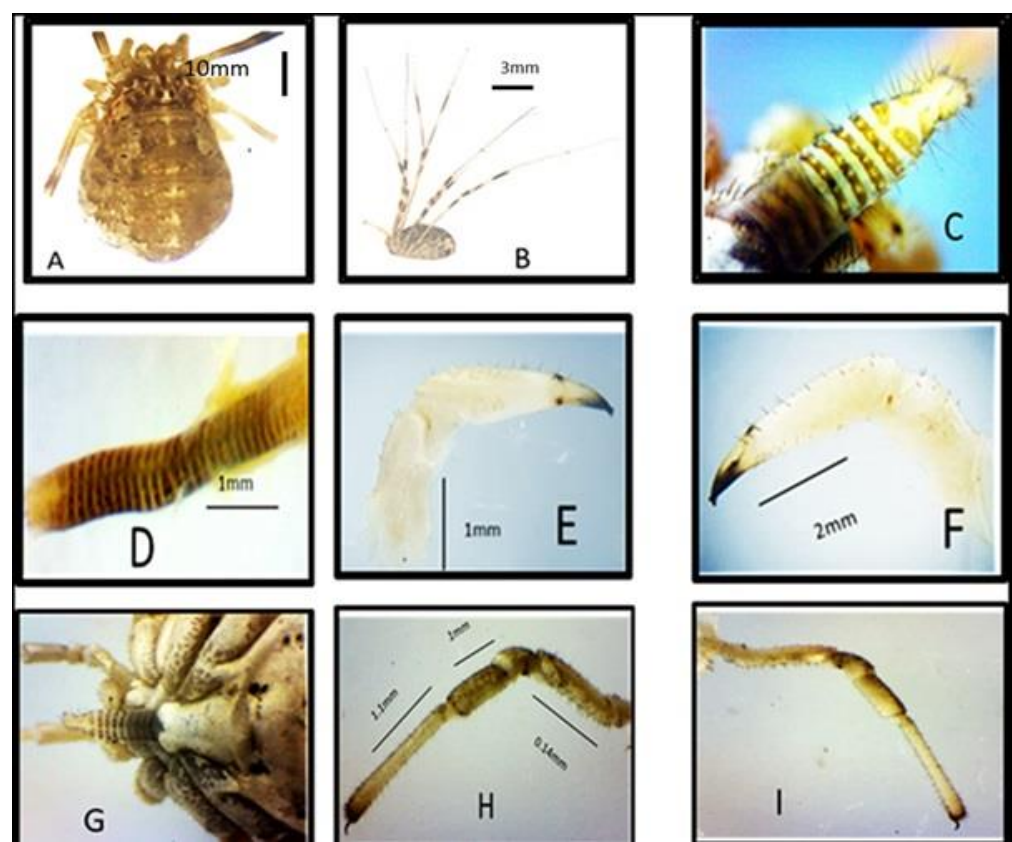

Plate (3): Female of Opilio kakunini; (A) Body, dorsal view,(B)Body, Latera view, (C) Distal end of ovipositor, (D) Ovipositor, (E) Chelicera, retrolateral view, (F) Chelicera, prolateral view,(G) Genital operculum, (H) Left pedipalp, prolateral view, (I) Left pedipalp, retrolateral view. 
First record of Opilio kakunini

\section{Habitat}

Individuals were collected from an agricultural field in Sayed Atta village and Al-Rifai district, north of Dhi-Qar province. The area of the field is equal to $17500 \mathrm{~m}^{2}$. It is bounded on one side by a fish lake and on the other side Al- Nadhimiyah stream, one of the branches of Al-Gharraf River, which is $9 \mathrm{~km}$ away from the collection region. The field is planted with fodder crops such as alfalfa and jet in addition to trees as species of Ziziphus and date palms. The specimens were found under the debris or have seen walking among the grasses or near the palm roots. All the specimens were observed active at night.

\section{Comment}

The species Opilio kakunini was first recorded by Snegovaya et al. (2018) in Iran, which shares common border with Iraq. O. kakunini is similar to O. parietinus; O. lederi Roewer, 1911; and $O$. arborphilus Snegovaya, 2010 morphologically, although it differs from all these species by the size, armature of chelicerae, pedipalps and the shape of the penis (Snegovaya, 2016).

Key to the identification of genera (Family, Phalangiidae) that recorded from Iraq:

1- Palpi femur mostly with ventral denticles or even thorns, patella and tibia with long apophysis apically, glans banana-shaped, coxa of leg without spots ventrally................................................ Rilaena Šilhavý, 1965

- Palpi femur without ventral denticles, no long apophysis on patella and tibia, glans shape different, coxa of leg with brown spots ventrally

Opilio Herbst, 1798

\section{Key to identify the species of Opilio in Iraq:}

1-Body quadrangular shape; penis corpus straight with little expansion at base; glans oval shape, with wide wing O. coxipunctus (Sørenson, 1912)

- Body oval shape; corpus widened in the basal third then tapers to the glans; glans nearly pear shaped.. O. kakunini Snegovaya, Cokendolpher \& Mozaffarian, 2018

The study of harvestmen in Iraq is thus far limited and according to a published data, only four species belong to family Phalangiidae, that have been recorded in this country (Starega1970 and 1973). The recording of O. kakunini in Iraq extends the checklist of harvestmen species in the country to five species. The current Iraqi fauna of harvestmen is far from being complete and more effort is needed to establish a comprehensive checklist of Opilio fauna in this region.

\section{ACKNOWLDGMENTS}

We are so grateful to Dr. Nataly Snegovaya from Azerbaijan national academy of science, for providing scientific advice. 


\section{Najim and Al-Fayyadh}

\section{LITERTURE CITED}

Cokendolpher, J. C. and Holmberg, R. G. 2018. Harvestmen of the family Phalangiidae (Arachnida: Opiliones) in the Americas. Special Publications / Museum of Texas Tech University, no. 67, 53pp.

Cokendolpher, J. C., Tsurusaki, N., Tourinho, A. L., Tylor, C.K., Gruber, J. and Pinto-daRocha, R. 2007. Taxonomy: Eupnoi. In: Pinto-da-Rocha, R., Machado, J. and Giribet, G. (Eds). The Biology of Opiliones, Massachusetts: Harvard University Press, p. 108131.

Hillyard, P.D. and Sankey, J. H.P. 1990.Harvestmen: keys and notes for the identification of the species. Synopses of British Fauna (Linnean Society of London), n.s., No. 4 ["1989"] [2nd edition of Sankey and Savory 1974]. E. j. Brill, Leiden, viii+ 120 pp.

Kury, A. B. 2013. Order Opiliones Sundevall, 1833. Zootaxa 3703 (1): 27-33.

Snegovaya, N. Y. 2016. Two new Opilio Herbst, 1798 species (Arachnida: Opiliones: Phalangiidae) from Caucasus region. Ecologica Montenegrina, 8: 27-33.

Snegovaya, N. Y. Cokendolpher, J. C. and Mozaffarian, F. 2018. The Opiliones of Iran with a description of a new genus and two new species. Journal of Arachnology, 46(1): 6980 .

Staręga, W. 1970. Eine neue Dircanolasma-Art aus Irak (Opiliones, Trgulidae). Bulletin de l'Acadèmie Polonaise des Sciences, Cl. II, Sèrie des Sciences Biologiques, 18 (8):475477.

Staręga, W. 1973. Beitrag Zur Kenntins der Weberknechte (Opiliones) des Nahen Ostens. Annales. Zoologici, 30 (6): 129-153.

Walker, M. E. 1928. A revision of the order Phalangiidae of Ohio. Ohio Biological Survey, Bulletin, 19(4):150-175. 


$$
\begin{aligned}
& \text { التسجيل الاول للنوع } \\
& \text { Opilio kakunini Snegovaya, Cokendolpher \& } \\
& \text { Mozaffarian, } 2018 \\
& \text { (Arachnida, Opiliones, Phalangiidae) } \\
& \text { في العراق }
\end{aligned}
$$

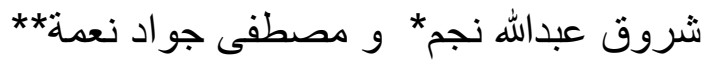

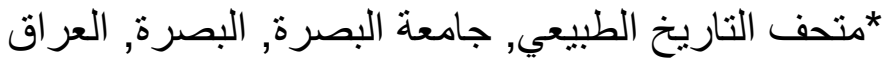

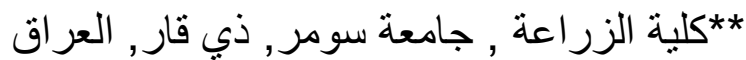

تأريخ الاستلام: 2021/01/06، تأريخ القبول: 2021/03/20، تأريخ النشر: 2021/6/20

\section{الخلاصة}

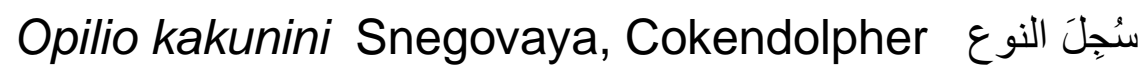

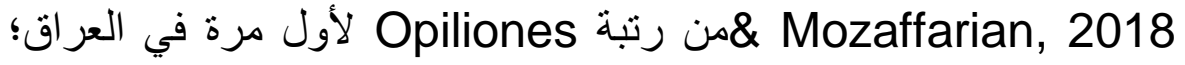

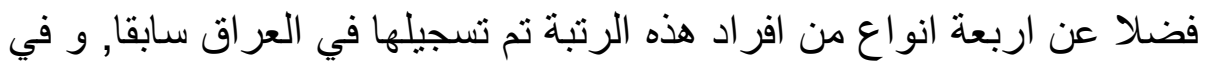

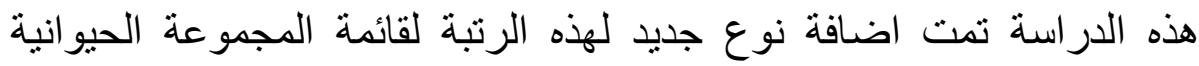

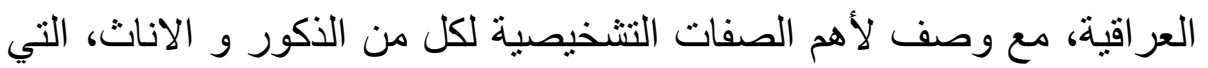
جمعت من قضاء الرفاعي شمال محافظة ذب قار جنوبي العراق. 